\title{
SIMULTANEOUS ESTIMATION OF CURCUMINOIDS, PIPERINE, AND GALLIC ACID IN AN AYURVEDIC FORMULATION BY VALIDATED HIGH-PERFORMANCE THIN LAYER CHROMATOGRAPHIC METHOD
}

\author{
NIRAJ VYAS*, SEJAL PATEL \\ Department of Pharmacognosy, Ramanbhai Patel College of Pharmacy, Charotar University of Science and Technology, CHARUSAT Campus, \\ Changa - 388 421, Gujarat, India. Email: nirajvyas.ph@charusat.ac.in \\ Received: 28 May 2016, Revised and Accepted: 20 June 2016
}

ABSTRACT

Objective: The present study was proposed to quantitatively estimate the amount of three marker compounds; curcuminoids, piperine, and gallic acid in a multicomponent ayurvedic formulation using high-performance thin layer chromatographic (HPTLC) method for routine analytical work.

Methods: TLC separation was performed on silica gel $60 \mathrm{~F}_{254}$ plates using toluene:ethyl acetate:formic acid:methanol (5.6:2.2:1.2:1.0 v/v/v/v) as mobile phase. Plate was developed by to a distance of $90 \mathrm{~mm}$ at ambient room temperature with 20 minutes saturation time. Densitometric analysis was performed at $327 \mathrm{~nm}$. Method was validated as per International Conference on Harmonization Q2 (R1) guideline also.

Results: Piperine, curcuminoids, and gallic acid were separated on TLC at retention factor values of $0.71,0.61$, and 0.29 , respectively. The described method was linear over the range of 300-700 ng/spot, 100-300 ng/spot, and 250-550 ng/spot, respectively, for curcuminoids, piperine, and gallic acid. The accuracy of the method was assessed by recovery studies and was found to be $101.71 \%, 99.67 \%$, and $99.59 \%$ for curcuminoids, piperine, and gallic acid, respectively. The amount of curcuminoids, piperine, and gallic acid in the ayurvedic formulation was found to be $3.99 \% \mathrm{w} / \mathrm{w}, 1.9 \%$ $\mathrm{w} / \mathrm{w}$, and $0.8 \% \mathrm{w} / \mathrm{w}$, respectively, when analyzed quantitatively by developed validated HPTLC method.

Conclusion: The method can be used as a tool for quality control of herbal formulation.

Keywords: Curcuminoids, Piperine, Gallic acid, High-performance thin layer chromatographic.

(C) 2016 The Authors. Published by Innovare Academic Sciences Pvt Ltd. This is an open access article under the CC BY license (http://creativecommons. org/licenses/by/4. 0/) DOI: http://dx.doi.org/10.22159/ajpcr.2016.v9s2.13131

\section{INTRODUCTION}

Curcuminoids present in turmeric is used as antiseptic in cut, wounds, inflammations, sore throat, urticaria, and skin allergies, whereas piperine, a constituent of black and long pepper, is used as bioavailability enhancer. Piperine is also reported to have antiallergic, antiasthmatic, hepatoprotective, antimalarial, and antiamoebic action. Gallic acid is used in dyspepsia, constipation, piles, enlarged liver, and spleen and also as an antioxidant [1].

Ayurvedic formulation "Haridrakhand" is used to treat urticaria and may skin diseases, and it contains these three herbs together. Thus, it is essential to ascertain the amount of each active phytoconstituent of plant present in the formulation. A literature survey revealed that high-performance thin layer chromatographic (HPTLC) [2-8], high-performance liquid chromatography [9-11], ultraviolet-visible spectroscopic [12], and spectrofluorimetric [13] methods had been developed for the determination of curcuminoids, piperine, and gallic acid individually. So, the present study is aimed to develop a validated HPTLC method for estimation of curcuminoids, piperine, and gallic acid simultaneously.

\section{METHODS}

\section{Plant materials and formulation}

Raw powdered plant materials mentioned in the formula for the preparation of ayurvedic formulation were procured from local market. Plant powders were identified and authenticated by taxonomist, Dr. A. M. Patel, J. and J. Science College, Nadiad, Gujarat, India. Sample specimens of plant powders were retained and submitted to the Department of Pharmacognosy, Ramanbhai Patel College of Pharmacy with voucher specimen No. 2010/PG/QA/SP. Ayurvedic formulation "Haridrakhand" was prepared as per the method described in Ayurvedic Formulary of India [14].

\section{Chemicals and materials}

All solvents and reagents used were of analytical grade and purchased from LOBA, India. Precoated silica gel $60 \mathrm{~F}_{254}$ TLC plates were obtained from Merck, Mumbai, India. Curcuminoids (95\%), piperine (98\%), and gallic acid (99\%) were obtained from Loba Chemie - Ahmedabad, Sigma-Aldrich - USA, and Himedia - Mumbai, respectively.

\section{Instrumentation}

Chromatographic separation was performed with CAMAG Linomat $\mathrm{V}$ sample applicator equipped with Hamilton Syringe and CAMAG TLC Scanner IV. Software win CATS version 1.4.7 was used for data acquisition.

\section{Preparation of ayurvedic lab formulation (Haridrakhand)}

All ingredients listed below in Table 1 were accurately weighed as per required quantity, powdered, mixed well, and passed through sieve. Starch paste and water were added to prepare sticky mass. Then sticky mass was passed through sieve $80 \#$, and granules were collected, air dried, and packed in air tight container.

\section{Preparation of standards and sample solutions}

About $10 \mathrm{mg}$ of each curcuminoid, piperine, and gallic acid were accurately weighed and transferred separately to a $10 \mathrm{ml}$ volumetric flask and dissolved in $10 \mathrm{ml}$ of methanol. The flask was sonicated in ultra sonicator bath for 15 minutes, and volume was made up to $10 \mathrm{ml}$ with methanol to give a stock solution containing $1000 \mu \mathrm{g} / \mathrm{ml}$ 
$(=1000 \mathrm{ng} / \mu \mathrm{l})$ each of curcuminoids, piperine, and gallic acid. From above stock solutions, working standards solutions of curcuminoids $(50 \mu \mathrm{g} / \mathrm{ml})$, piperine $(50 \mu \mathrm{g} / \mathrm{ml})$, and gallic acid $(50 \mu \mathrm{g} / \mathrm{ml})$ were prepared in methanol.

About $40 \mathrm{~g}$ of formulation was extracted with methanol at $60^{\circ} \mathrm{C}$ for $3 \mathrm{hrs}$. Extract was cooled, filtered through Whatman filter paper, and diluted to $200 \mathrm{ml}$ with methanol. This solution served as sample solution for determination of the three marker compounds.

\section{Optimized chromatographic conditions}

- Stationary phase: $20 \mathrm{~cm} \times 10 \mathrm{~cm}$ silica gel $60 \mathrm{~F}_{254}$ TLC plates of 0.2 mm layer thickness

- Mobile phase: Toluene:ethyl acetate:formic acid:methanol (5.6:2.2:1.2:1.0 v/v/v/v)

- Development technique: Ascending double development technique in same mobile phase

- Chamber saturation time: 20 minutes for each development

- Run distance: $90 \mathrm{~mm}$ for each development

- Scanning wavelength: $327 \mathrm{~nm}$

- Temperature: Ambient room temperature

- Band length: $8 \mathrm{~mm}$.

The identity of bands of sample extracts was confirmed by the retention factor values (Fig. 1) and by overlaying the absorption spectrum with that of standards using the CAMAG TLC Scanner IV.

\section{Method validation}

The developed HPTLC method was validated as per International Conference on Harmonization (ICH) guideline Q2 (R1) with respect to selectivity, linearity, precision, accuracy, limit of detection (LOD), limit of quantification (LOQ), and robustness [15].

\section{Linearity and range $(n=6)$}

Different volumes of standard solutions of curcuminoids, piperine, and gallic acid (2-15 $\mu \mathrm{l}$ ) were applied to the plate (Table 2 ). Calibration curves were plotted, and linear response of concentration versus absorbance was observed over a concentration range of 300-700 ng/spot, 100-300 ng/spot, and 250-550 ng/spot for curcuminoids, piperine, and gallic acid, respectively.

\section{Precision $(\mathrm{n}=\mathbf{3})$}

Precision of the developed method was studied by performing intraday precision and inter-day precision studies.

The intra-day precision was determined by analyzing three different concentrations of curcuminoids (300,500, and $700 \mathrm{ng} / \mathrm{spot})$, piperine $(100,200$, and $300 \mathrm{ng} / \mathrm{spot})$, and gallic acid (250, 400, and $550 \mathrm{ng} / \mathrm{spot})$ 6 times in a day. Inter-day precision was determined by analyzing three different concentrations of curcuminoids $(300,500$, and $700 \mathrm{ng} / \mathrm{spot})$, piperine $(100,200$, and $300 \mathrm{ng} / \mathrm{spot})$, and gallic acid $(250,400$, and

Table 1: Composition for preparation of ayurvedic lab formulation (Haridrakhand)

\begin{tabular}{lll}
\hline No. & Ingredient & Quantity \\
\hline 1 & Turmeric & $37.5 \mathrm{~g}$ \\
2 & Chitraka & $2 \mathrm{~g}$ \\
3 & Black cumin & $2 \mathrm{~g}$ \\
4 & Vidang & $2 \mathrm{~g}$ \\
5 & Ginger & $2 \mathrm{~g}$ \\
6 & Black pepper & $2 \mathrm{~g}$ \\
7 & Long pepper & $2 \mathrm{~g}$ \\
8 & Triphala & $2 \mathrm{~g}$ \\
9 & Rock salt & $2 \mathrm{~g}$ \\
10 & Lactose & $37.5 \mathrm{~g}$ \\
11 & Starch paste & $18.5 \mathrm{~g}$ \\
12 & Water (vehicle) & $75 \mathrm{ml}$ \\
\hline
\end{tabular}

$550 \mathrm{ng} / \mathrm{spot}) 6$ times on six consecutive days. The results are shown in Table 3.

Accuracy $(n=3)$

The accuracy was measured by performing recovery study. It was performed in triplicate by standard addition method at $80 \%, 100 \%$,

Table 2: Linearity and range for curcuminoids, piperine, and gallic acid ( $n=6)$

\begin{tabular}{clll}
\hline No. & $\begin{array}{l}\text { Concentration } \\
\text { (ng/spot) }\end{array}$ & Mean area \pm SD & RSD \% \\
\hline Curcuminoids & & & \\
1 & 300 & $2304.93 \pm 30.91$ & 1.34 \\
2 & 400 & $3164.40 \pm 65.47$ & 2.06 \\
3 & 500 & $4030.63 \pm 45.78$ & 1.13 \\
4 & 600 & $4561.31 \pm 36.02$ & 0.78 \\
5 & 700 & $5419.23 \pm 37.36$ & 0.68 \\
Piperine & & & \\
1 & 100 & $2653.23 \pm 14.58$ & 0.54 \\
2 & 150 & $3631.00 \pm 30.61$ & 0.84 \\
3 & 200 & $4643.06 \pm 16.76$ & 0.36 \\
4 & 250 & $5568.60 \pm 25.85$ & 0.46 \\
5 & 300 & $6471.18 \pm 40.96$ & 0.63 \\
Gallic acid & & & \\
1 & 250 & $1258.73 \pm 24.52$ & 1.94 \\
2 & 300 & $1396.28 \pm 12.22$ & 0.87 \\
3 & 350 & $1637.66 \pm 33.62$ & 2.05 \\
4 & 400 & $1982.10 \pm 37.79$ & 1.90 \\
5 & 450 & $2166.20 \pm 22.82$ & 1.05 \\
6 & 500 & $2393.51 \pm 15.36$ & 0.64 \\
7 & 550 & $2607.98 \pm 29.51$ & 1.13 \\
\hline
\end{tabular}

RSD: Relative standard deviation, SD: Standard deviation

Table 3: Intra- and inter-day precision $(n=6)$

\begin{tabular}{|c|c|c|c|c|c|}
\hline \multirow[t]{2}{*}{$\begin{array}{l}\text { Name of the } \\
\text { compounds }\end{array}$} & \multirow[t]{2}{*}{$\begin{array}{l}\text { Amount } \\
\text { (ng/spot) }\end{array}$} & \multicolumn{2}{|c|}{$\begin{array}{l}\text { Intra-day } \\
\text { precision }\end{array}$} & \multicolumn{2}{|c|}{$\begin{array}{l}\text { Inter-day } \\
\text { precision }\end{array}$} \\
\hline & & SD & RSD \% & SD & RSD \% \\
\hline \multirow[t]{3}{*}{ Curcuminoids } & 300 & 29.672 & 1.241 & 37.597 & 1.689 \\
\hline & 500 & 28.760 & 0.689 & 40.612 & 1.285 \\
\hline & 700 & 48.194 & 0.856 & 51.187 & 1.221 \\
\hline \multirow[t]{3}{*}{ Piperine } & 100 & 38.339 & 1.463 & 40.193 & 1.535 \\
\hline & 200 & 17.079 & 0.369 & 53.554 & 1.159 \\
\hline & 300 & 62.952 & 0.984 & 66.386 & 1.039 \\
\hline \multirow[t]{3}{*}{ Gallic acid } & 250 & 14.169 & 1.025 & 17.854 & 1.219 \\
\hline & 400 & 19.964 & 1.004 & 17.587 & 1.122 \\
\hline & 550 & 9.163 & 0.449 & 16.494 & 1.287 \\
\hline
\end{tabular}

RSD: Relative standard deviation, SD: Standard deviation

Table 4: Results of accuracy study $(n=6)$

\begin{tabular}{lllll}
\hline $\begin{array}{l}\text { Name of the } \\
\text { compounds }\end{array}$ & $\begin{array}{l}\text { Amount of } \\
\text { standard } \\
\text { spiked (ng) }\end{array}$ & $\begin{array}{l}\text { Average } \\
\text { of amount } \\
\text { recovered } \\
\text { (ng) }\end{array}$ & $\begin{array}{l}\text { Recovery } \\
\text { (\%) } \pm \text { SD }\end{array}$ & RSD \% \\
\hline Curcuminoids & 0 & 1605.28 & - & - \\
& 40 & 1627.19 & $99.46 \pm 1.119$ & 1.125 \\
& 80 & 1712.35 & $101.60 \pm 2.764$ & 2.720 \\
Piperine & 120 & 1795.58 & $104.07 \pm 2.950$ & 2.834 \\
& 0 & 303.09 & - & - \\
& 40 & 346.47 & $101.00 \pm 2.737$ & 2.709 \\
Gallic acid & 0 & 378.51 & $98.80 \pm 0.059$ & 0.059 \\
& 120 & 420.23 & $99.23 \pm 0.833$ & 0.839 \\
& 40 & 179.23 & - & - \\
& 80 & 215.44 & $98.27 \pm 0.257$ & 0.261 \\
& 120 & 260.65 & $100.11 \pm 1.808$ & 1.806 \\
& 298.07 & $100.40 \pm 1.333$ & 1.327 \\
\hline
\end{tabular}

RSD: Relative standard deviation, SD: Standard deviation 
and $120 \%$ of the standards. Known amount of standards were added to pre-analyzed samples, and the total amount of each of the markers was determined by the developed method. Average percentage recovery of each marker is reported in Table 4

\section{LOD and LOQ}

The LOD and LOQ of the developed method were calculated from the standard deviation of the response and slope of the calibration curves of curcuminoids, piperine, and gallic acid using the formulae as given below.

\section{$\mathrm{LOD}=3.3 \sigma / \mathrm{S}$ and $\mathrm{LOQ}=10 \sigma / \mathrm{S}$}

Where $\sigma$ is the standard deviation of the response and S is the slope of the calibration curve.

Results are indicated in Table 5.

\section{Specificity}

The specificity of the method was ascertained by analyzing standard drug and sample. The method was found to be specific for curcuminoids, piperine, and gallic acid because it resolved the peaks of the drugs in the presence of other excipients as shown in Figs. 2-4.
The specificity was also confirmed by superimposition of UV spectra of standard and sample recorded by scanner IV. The spectra are shown in Fig. 5.

Correlation between these spectra confirmed the purity of the curcuminoids peak correlation $(\mathrm{r}(\mathrm{s}, \mathrm{m})=0.9996, \mathrm{r}(\mathrm{m}, \mathrm{e})=0.9997)$ piperine peak correlation $(\mathrm{r}(\mathrm{s}, \mathrm{m})=0.9999, \mathrm{r}(\mathrm{m}, \mathrm{e})=0.9998)$, and for gallic acid peak correlation $(r(s, m)=0.9999, r(m, e)=0.9998)$, respectively. Thus, it can be concluded that the excipients did not interfere with the peaks from standard drug solutions.

\section{Robustness study}

The robustness of the method was checked by introducing small deliberate changes in various method parameters such as mobile phase

Table 5: LOD and LOQ (ng/spot) $(n=6)$

\begin{tabular}{llll}
\hline $\begin{array}{l}\text { Name of the } \\
\text { compounds } \\
\text { (ng/spot) }\end{array}$ & Curcuminoids & Piperine & $\begin{array}{l}\text { Gallic } \\
\text { acid }\end{array}$ \\
\hline LOD & 1.388 & 4.784 & 14.770 \\
LOQ & 4.207 & 14.497 & 44.759 \\
\hline
\end{tabular}

LOD: Limit of detection, LOQ: Limit of quantification

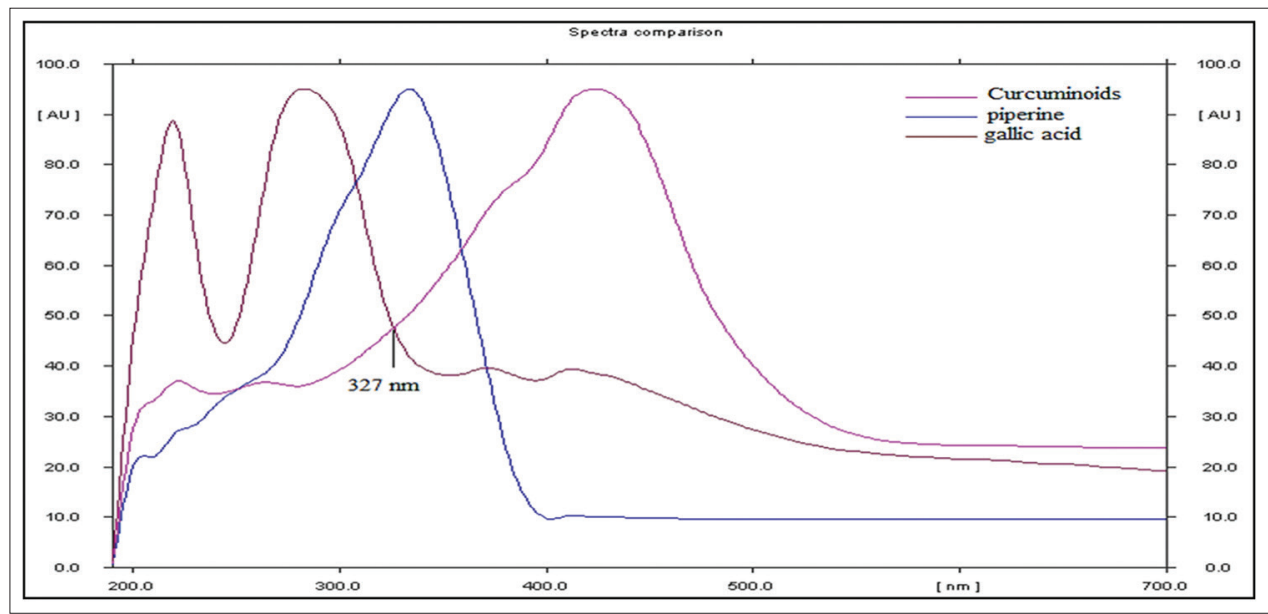

Fig. 1: Selection of analytical wavelength

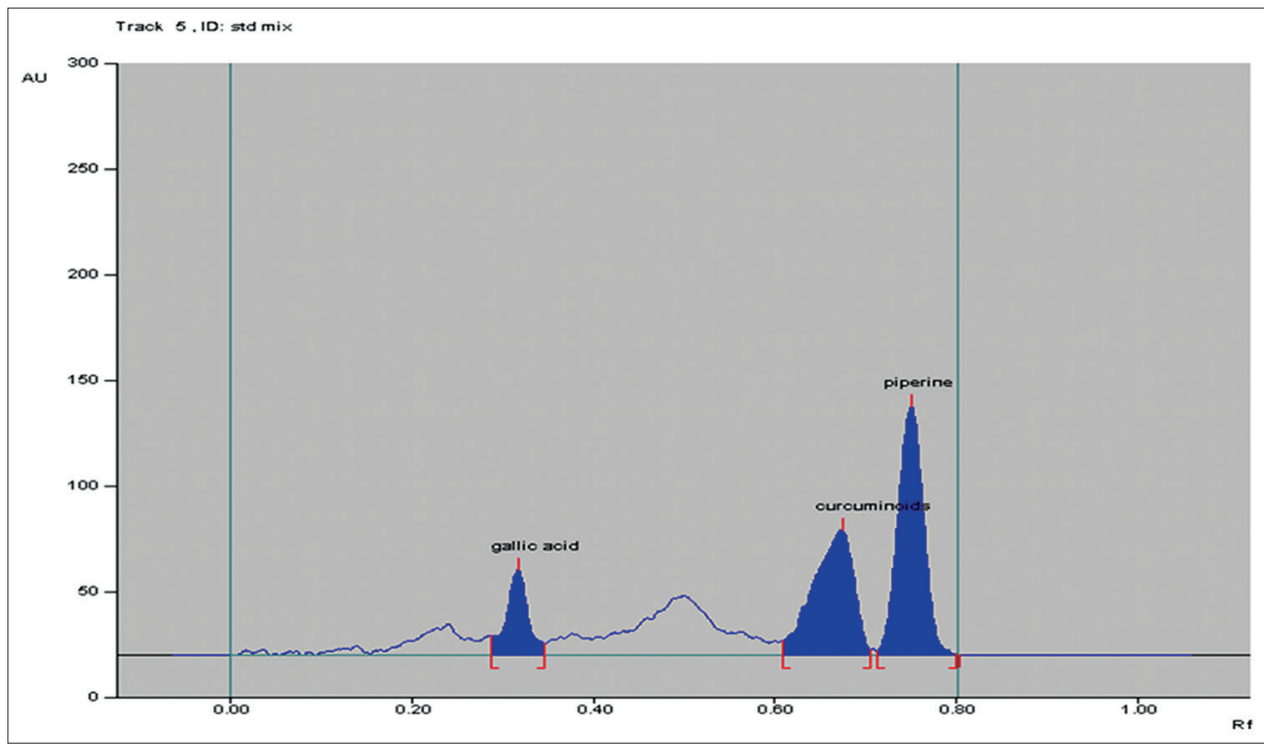

Fig. 2: Chromatogram obtained from the standard mixture, piperine, curcuminoids, and gallic acid are present in at retention factor $\left(R_{\mathrm{f}}\right) \sim 0.71, \mathrm{R}_{\mathrm{f}} \sim 0.61$, and $\mathrm{R}_{\mathrm{f}} \sim 0.29$, respectively 


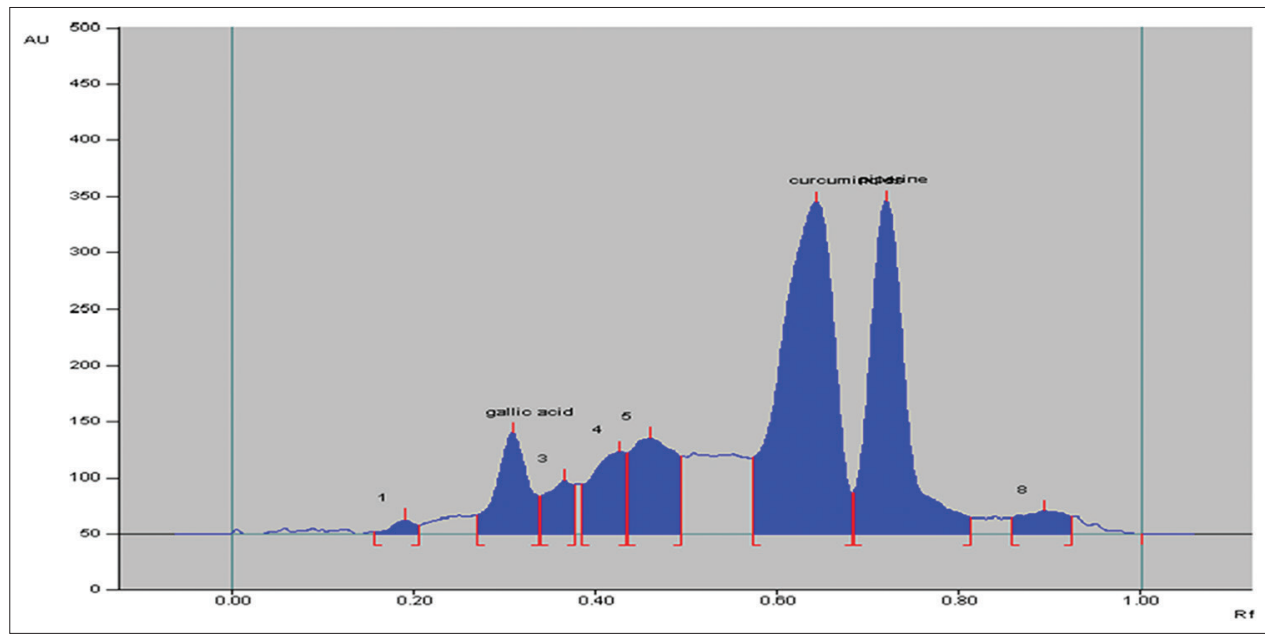

Fig. 3: Chromatogram obtained from the ayurvedic formulation, piperine, curcuminoids, and gallic acid are present in at retention factor $\left(R_{\mathrm{f}}\right) \sim 0.71, \mathrm{R}_{\mathrm{f}} \sim 0.61$, and $\mathrm{R}_{\mathrm{f}} \sim 0.29$, respectively

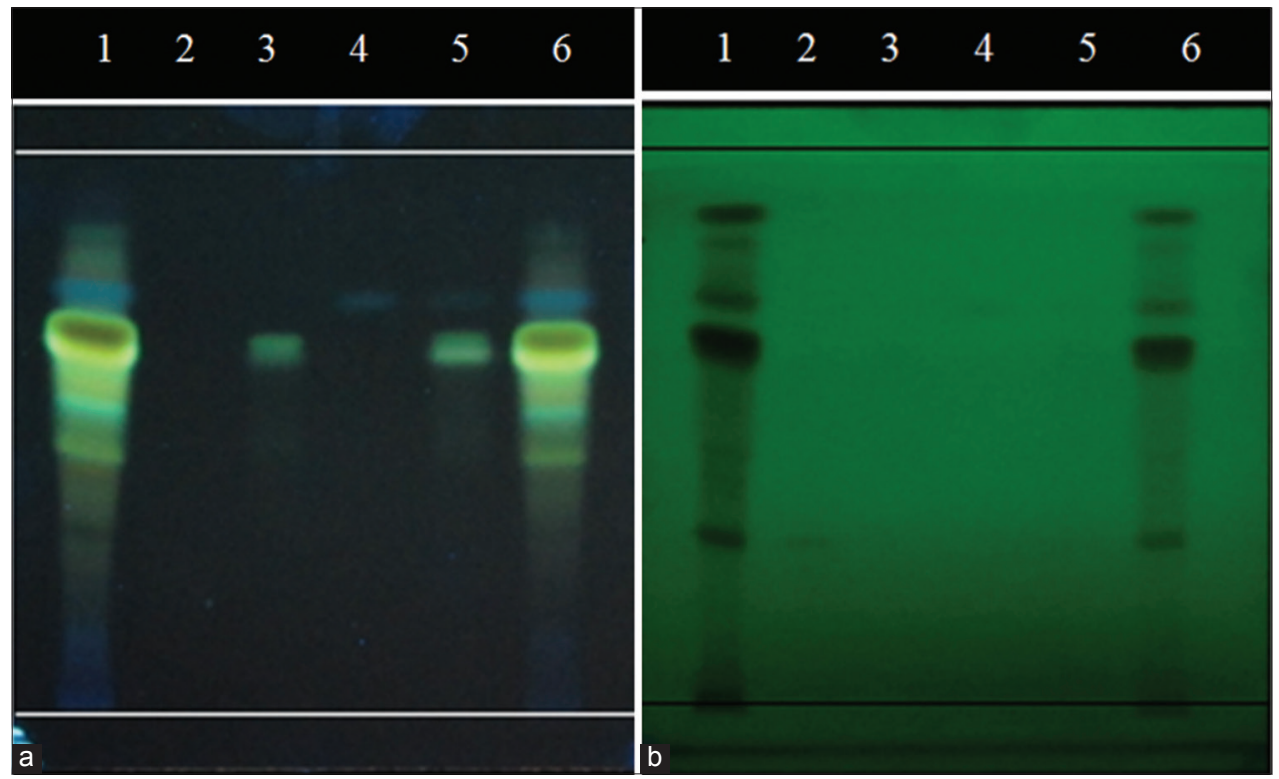

Fig. 4: Thin layer chromatographic profile obtained from the ayurvedic formulation, curcuminoids, piperine, and gallic acid standards (a) at $\lambda=366 \mathrm{~nm}$ (b) at $\lambda=254 \mathrm{~nm}$. 1 and 6 are sample track, 5 is standard mixture track, 2, 3, and 4 are track of standard gallic acid, curcuminoids, and piperine, respectively

Table 6: Robustness of HPTLC method ( $n=6)$

\begin{tabular}{|c|c|c|c|c|c|c|}
\hline \multirow[t]{2}{*}{ Parameter } & \multicolumn{2}{|c|}{ Curcuminoids } & \multicolumn{2}{|l|}{ Piperine } & \multicolumn{2}{|l|}{ Gallic acid } \\
\hline & $\begin{array}{l}\text { SD of peak } \\
\text { area }\end{array}$ & $\begin{array}{l}\text { RSD } \\
\%\end{array}$ & $\begin{array}{l}\text { SD of peak } \\
\text { area }\end{array}$ & $\begin{array}{l}\text { RSD } \\
\%\end{array}$ & $\begin{array}{l}\text { SD of peak } \\
\text { area }\end{array}$ & $\begin{array}{l}\text { RSD } \\
\%\end{array}$ \\
\hline Mobile phase volume $(20 \pm 3 \mathrm{ml})$ & 348.750 & 1.968 & 51.934 & 0.478 & 2.732 & 0.105 \\
\hline Pretreatment of plate with methanol & 139.124 & 0.787 & 124.345 & 1.177 & 7.399 & 0.092 \\
\hline Durationof saturation ( $20 \pm 5$ minutes $)$ & 81.251 & 1.166 & 119.290 & 1.153 & 93.427 & 1.669 \\
\hline
\end{tabular}

HPTLC: High-performance thin layer chromatographic, RSD: Relative standard deviation, SD: Standard deviation

volume, duration of saturation, pre-treatment of plate with methanol, and the results are examined and described in (Table 6). The relative standard deviation (RSD) [\%] obtained after a small change in the parameters was used as an indicator of the robustness of the method. The RSD values $<2$ indicate the robustness of the method.

Quantification of markers in ayurvedic formulation

The developed method was applied to the determination of curcuminoids, piperine, and gallic acid in the ayurvedic formulation.
From test solution, $8 \mu \mathrm{l} /$ spot was applied on HPTLC plate, and results were obtained which described in Table 7.

\section{RESULTS AND DISCUSSION}

The developed HPTLC method provides a simple, precise, and accurate analytical method for simultaneous estimation of curcuminoids, piperine, and gallic acid in the ayurvedic formulation. A good separation of analytes was achieved using mobile phase composed of 


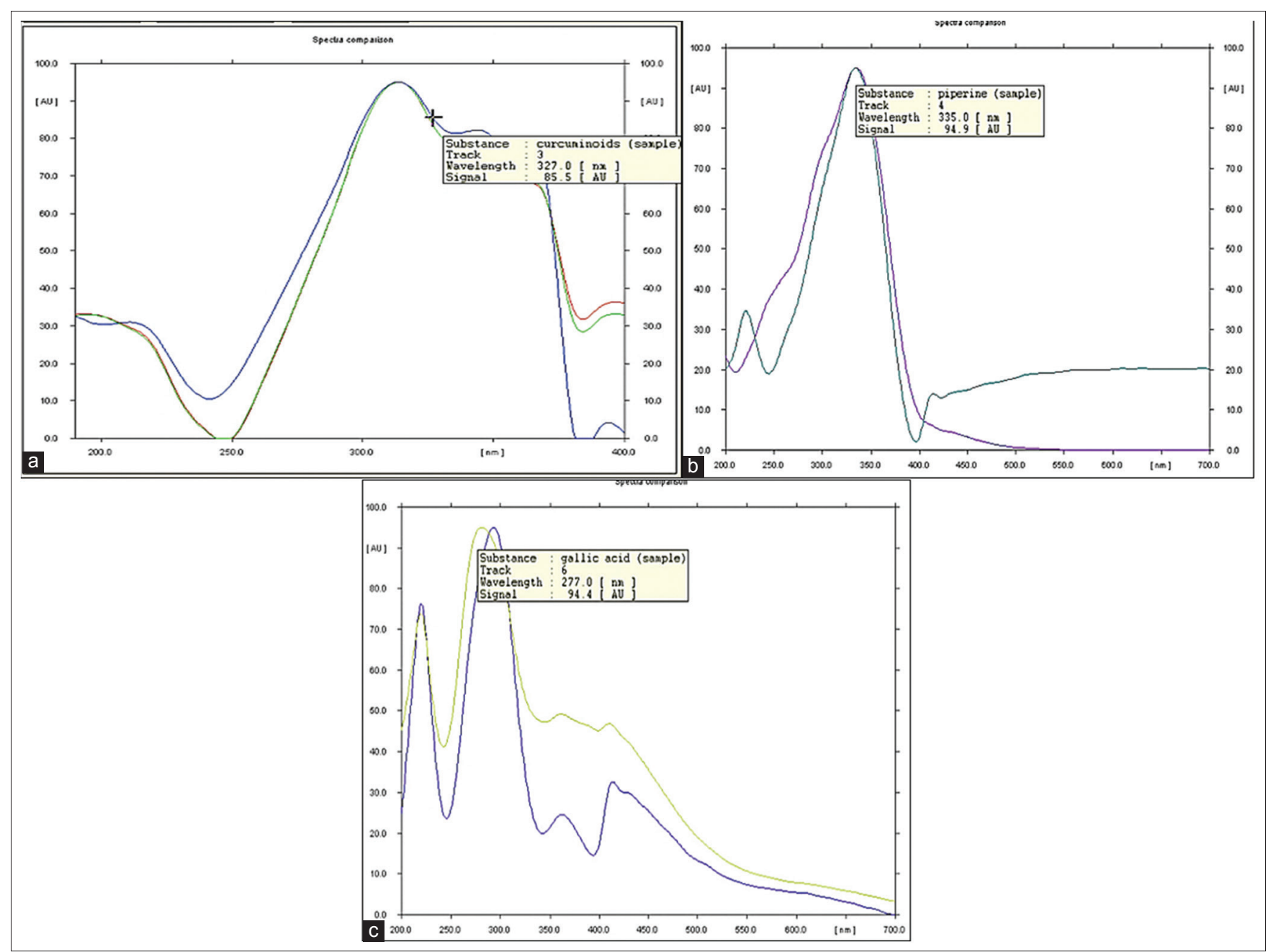

Fig. 5: Selectivity- superimposed spectra of curcuminoids (a), piperine (b), and gallic acid (c) from standard and sample solution

Table 7: Content of curcuminoids, piperine, and gallic acid in ayurvedic formulation $(n=6)$

\begin{tabular}{llll}
\hline $\begin{array}{l}\text { Name of the } \\
\text { compounds }\end{array}$ & Curcuminoids (\%) & Piperine & Gallic acid \\
\hline $\begin{array}{l}\text { Average content } \\
(\% \mathrm{w} / \mathrm{w})\end{array}$ & 3.99 & 1.9 & 0.80 \\
\hline
\end{tabular}

toluene:ethyl acetate:formic acid:methanol (5.6:2.2:1.2:1.0 v/v/v/v) on precoated silica gel $60 \mathrm{~F}_{254}$ plates. \% RSD value $<2$ in every parameter of validation procedures described in ICH Q2 (R1) guideline indicates that the method is validated. The present HPTLC method is found to be relatively specific, precise, and accurate. The developed, validated method was also employed to estimate the amount of markers quantitatively in the ayurvedic formulation. Thus, this method can be used as a tool for routine analysis of these three marker compounds in any multicomponent herbal or ayurvedic formulation for quality control.

\section{CONCLUSION}

The amount of curcuminoids, piperine, and gallic acid in the ayurvedic formulation was found to be $3.99 \% \mathrm{w} / \mathrm{w}, 1.9 \% \mathrm{w} / \mathrm{w}$, and $0.8 \% \mathrm{w} / \mathrm{w}$, respectively. Further, this method can be effectively used for routine quality control of herbal materials as well as ayurvedic and herbal formulations containing any of these three compounds.

\section{ACKNOWLEDGMENT}

The authors wish to express their thanks to Ramanbhai Patel College of Pharmacy, for providing the necessary facilities for performing this research work.

\section{REFERENCES}

1. Anonymous. Indian Herbal Pharmacopoeia, Revised New Edition. New Delhi: A Joint Publication of RRL and Indian Drug's Manufacturer's Association; 2002.

2. Gupta AP, Gupta MM, Kumar S. Simultaneous determination of curcuminoids in Curcuma samples using high performance thin layer chromatography. J Liq Chromatogr Relat Technol 1999;22(10):1561-9.

3. Khan S, Makhija IK, Khamar D, Rani S. Development and standardization of turmeric cream by HPTLC. Int J Biomed Adv Res 2010;1(4):109-16.

4. Tapadiya G, Metku M, Deokate U, Khadabadi S, Saboo S, Sahu K. Quantitative estimation of piperine from pharmaceutical dosage form by HPTLC. Asian J Pharm Clin Res 2009;2(2):47-50.

5. Hamrapurkar PD, Jadhav K, Zine S. Quantitative estimation of piperine in Piper nigrum and Piper longum using high performance thin layer chromatography. J Appl Pharm Sci 2011;1(3):117-20.

6. Sawant L, Pandita N, Prabhakar B. Determination of gallic acid in Phyllanthus emblica Linn. Dried fruit powder by HPTLC. J Pharm Bioallied Sci 2010;2(2):105-8.

7. Rakesh SU, Salunkhe VR, Dhabale PN, Burade KB. HPTLC method for quantitative determination of gallic acid in hydroalcoholic extract of dried flowers of Nymphaea stellata Willd. Asian J Res Chem 
2009;2(2):131-4

8. Vyas N, Gamit K, Khan MY, Panchal S, Pundarikakshudu K Simultaneous estimation of curcumin and piperine in their crude powder mixture and ayurvedic formulation using high performance: Thin layer chromatography. Int J Res Pharm Biomed Sci 2011;2(1):231-6.

9. Heath DD, Pruitt MA, Brenner DE, Rock CL. Curcumin in plasma and urine: Quantitation by high-performance liquid chromatography. J Chromatogr B Analyt Technol Biomed Life Sci 2003;783(1):287-95.

10. Sunita S, Menon S, Singh A. Quantitative analysis of piperine from ayurvedic polyherbal formulations using reverse phase high performance liquid chromatography. Int J Pharm Bio Sci 2010;1:1-10.

11. Deshmukh H, Prabhu PJ. Development of RP-HPLC method for qualitative analysis of active ingredient (gallic acid) from stem bark of Dendrophthoe falcata Linn. Int J Pharm Sci Drug Res 2011;3(2):146-9.

12. Gupta V, Jain UK. Quantitative estimation of piperine in Pancasama churna by RP-HPLC. Der Pharm Lett 2011;3(1):400-6.

13. Gupta NK, Nahata A, Dixit VK. Development of a spectrofluorimetric method for the determination of curcumin. Asian J Tradit Med 2010;5(1):51-7.

14. Mishra B. Bhaisajya Ratnavali of Govinda Dasji Bhisagratna New Delhi: Chaukhambha Publication 2008, 1,703.

15. ICH. Q2 (R1), Validation of Analytical Procedures: Methodology. In: Proceedings of the International Conference on Harmonization: Geneva, November; 1996 